\title{
The ageing entero-insular axis
}

\author{
L. Ranganath ${ }^{1}$, I. Sedgwick ${ }^{2}$, L. Morgan ${ }^{2}$, J. Wright ${ }^{2}$, V. Marks ${ }^{2}$ \\ ${ }^{1}$ Epsom General Hospital, Epsom, Surrey, UK \\ ${ }^{2}$ School of Biological Sciences, University of Surrey, Guildford, Surrey, UK
}

Summary Ageing is one of the major risk factors for glucose intolerance including impaired glucose tolerance and Type II (non-insulin-dependent) diabetes mellitus. Reduced insulin secretion has been described as part of normal ageing although there is no information on age-related changes in the secretion of the major insulinotropic hormones, glucose-dependent insulinotropic polypeptide (GIP) and glucagon-like peptide (7-36 amide) (GLP-1). We assessed the entero-insular axis in 6 young premenopausal and 6 older postmenopausal women following treatment with oral carbohydrate. Insulin and glucose integrated responses were similar in the younger and older groups. Total integrated responses for GIP and GLP-1 were considerably greater in the older subjects. A positive correlation between age and total in- tegrated responses for glucose $(r=0.65 ; p<0.02)$ as well as GLP-1 $(r=0.85 ; p<0.001)$ was seen. We hypothesise that an age-related impairment of insulin secretion to insulinotropic hormones, GIP and GLP1 , contributes to a reduction in glucose tolerance in this age group. The pronounced compensatory increase in postprandial secretion of GIP and GLP-1 provides further evidence not only for the negative feedback relation between incretin and insulin secretion but also for the importance of the entero-insular axis in the regulation of insulin secretion. [Diabetologia (1998) 41: 1309-1313]

Keywords GLP-1, GIP, insulin, glucose, elderly, menopause.
Ageing is associated with a greater prevalence of impaired glucose tolerance and Type II (non-insulin-dependent) diabetes mellitus which can be associated with both a decrease in insulin secretion as well as an increase in insulin resistance $[1,2]$.

Studies in humans have shown that insulin secretion decreases with age independent of adiposity, distribution of fat and physical activity [3]. The reduction in insulin secretion in older human subjects has been attributed to decreasing responsiveness of the

Received: 14 January 1998 and in revised form: 12 June 1998

Corresponding author: Dr L. Ranganath, Department of Chemical Pathology, Epsom General Hospital, Epsom, Surrey KT18 7EG, UK

Abbreviations: GIP, Glucose-dependent insulinotropic polypeptide; GLP-1, glucagon-like peptide-1; CV, coefficient of variance. beta cell to glucose [4]; defects of both early and late phase insulin secretion after intravenous glucose administration have been shown in the elderly [5]. In addition, there is evidence that ageing is associated with defective intra-pancreatic processing of insulin since even those older subjects with normal glucose tolerance have been shown to have greatly increased proinsulin secretion as well as proinsulin-to-insulin molar ratios [6].

Animal studies have shed further light on the impact of ageing on the biology of insulin secretion. In the rat, ageing is characterised by a high insulin content in the islet but decreased insulin secretion due primarily to impairment of beta-cell stimulus-secretion coupling which leads to greater intracellular insulin degradation secondary to failure of secretion [7]. In older mice, although islets are larger and the number of beta cells per islet is greater, the number of beta cells secreting insulin following glucose stimu- 
Table 1. Details of subjects and fasting levels

\begin{tabular}{lll}
\hline & $\begin{array}{l}\text { Younger group } \\
\text { Means } \pm \text { SEM }\end{array}$ & $\begin{array}{l}\text { Older group } \\
\text { Means } \pm \text { SEM }\end{array}$ \\
\hline Age (years) & $23.2^{\mathrm{b}}(1.8)$ & $67.5(4.1)$ \\
Weight $(\mathrm{kg})$ & $65.0(3.1)$ & $65.7(2.0)$ \\
BMI $\left(\mathrm{kg} / \mathrm{m}^{2}\right)$ & $23.8(1.1)$ & $25.5(0.9)$ \\
Plasma glucose $(\mathrm{mmol} / \mathrm{l})$ & $4.9^{\mathrm{a}}(0.1)$ & $5.3(0.2)$ \\
Plasma insulin $(\mu \mathrm{U} / \mathrm{ml})$ & $6.72(1.19)$ & $5.75(1.27)$ \\
Plasma GIP $(\mathrm{pmol} / \mathrm{l})$ & $25(4.8)$ & $36(6)$ \\
Plasma GLP-1 $(\mathrm{pmol} / \mathrm{l})$ & $12.4^{\mathrm{a}}(1.2)$ & $18.2(1.9)$ \\
\hline
\end{tabular}

$n=6$ in each group; younger vs older: ${ }^{\mathrm{a}} p<0.05 ;{ }^{\mathrm{b}} p<0.0001$

lation is reduced as is the output of insulin per cell and the level of insulin mRNA in the islet [8]. Both qualitative and quantitative defects in glucose-mediated insulin secretion were shown in the beta cell of old rats, including abnormalities of calcium channels and cyclic AMP-dependent exocytosis [9].

It is thus clear that ageing, in animals and humans, is associated with a selective beta-cell dysfunction characterised by reduced insulin secretion in response both to glucose and to other secretogogues, predisposing to impaired glucose tolerance and diabetes mellitus.

The concept that intestinal hormones or 'incretins' are involved in the augmentation of insulin secretion in response to oral compared with intravenous glucose is embodied in the classical descriptions of the 'entero-insular' axis [10,11]. The two major hormones of the entero-insular axis are believed to be glucose-dependent insulinotropic polypeptide (GIP) and glucagon-like peptide-1 (GLP-1) [12], both of which have been shown to act as incretins, exerting a synergic effect in increasing the insulin response to oral feeding in the presence of hyperglycaemia. Despite the possibility that abnormalities of the enteroinsular axis contribute to impaired insulin secretion in the elderly, there are not published data on the effect of ageing on the secretion of the insulinotropic hormone, GIP and GLP-1, either in animals or in humans.

Preliminary studies in our department suggested that there could be marked differences in postprandial GLP-1 secretion between younger and older subjects and our unpublished observations [13]. The aim of this study was to investigate the effect of ageing on the post-carbohydrate secretion of these hormones, and relate this to carbohydrate tolerance and gastric emptying. Gastric emptying was assessed by measurement of plasma paracetamol concentrations after an oral dose of paracetamol given with the carbohydrate load $[14,15]$.

\section{Subjects and methods}

Study protocol. The study protocols were approved by the South West Surrey Local Research Ethics Committee. Written consent was obtained from all participants.

Subjects. Healthy young premenopausal women $(n=6)$ and healthy older postmenopausal women $(n=6)$ were recruited. All subjects were non-smokers and none was taking any medication. Subject details are shown in Table 1.

Experimental procedures. All subjects attended for study on a single occasion after an overnight fast of $12 \mathrm{~h}$, having abstained from alcohol for $24 \mathrm{~h}$ prior to study. Studies were carried out with the subjects seated at rest. An indwelling cannula was sited in a forearm vein and maintained patent with saline. Venous blood samples were collected via the cannula before $(-15$ and 0 minutes) and at 15, 30, 45, 60, 90, 120, 180, 240, 300 and $360 \mathrm{~min}$ after administration of $100 \mathrm{~g}$ carbohydrate given as $155 \mathrm{ml}$ of Hycal (Smith Kline Beecham, Brentwood, Herts, UK) made up to a volume of $300 \mathrm{ml}$ with water and containing $1.5 \mathrm{~g}$ of soluble paracetamol (Panadol, Smith Kline Beecham).

Blood samples. Blood samples were taken into heparinised tubes containing aprotinin $(1000 \mathrm{KIU} / \mathrm{ml}$ blood) for paracetamol, insulin, GIP and GLP-1; into tubes containing fluoride/ oxalate for glucose; and into plain glass bottles for paracetamol measurements. Samples were centrifuged immediately at $1200 \mathrm{~g}$ for $5 \mathrm{~min}$; plasma was separated and frozen at $-20^{\circ} \mathrm{C}$ in aliquots until analysis. Blood collected into plain glass bottles for paracetamol analysis was centrifuged $30 \mathrm{~min}$ after collection at $1200 \mathrm{~g}$ for $5 \mathrm{~min}$, and serum was separated and stored at $-20^{\circ} \mathrm{C}$ until analysis.

Laboratory assays. Glucose and paracetamol were measured by enzymatic methods with an inter-assay coefficient of variance $(\mathrm{CV})$ of less than $5 \%$. Insulin was measured in Germany (at Institut Dr Schaper, Dresden) using an Abbott IMx assay (Abbot/Diagnostika, Wiesbaden, Germany) with CV of 4.2 and $9.0 \%$ at 50 and $500 \mu \mathrm{U} / \mathrm{ml}$, respectively [19].

The GIP assay used has been described previously [16, 17]; synthetic human GIP was used for the preparation of the standards and iodinated tracer (purified immediately prior to use by affinity chromatography) and the antiserum was raised in rabbits against natural porcine GIP; a PEG (polyethylene glycol 6000, BDH Laboratory supplies, Poole, UK)-accelerated double antibody phase separation stage was used. The detection limit of the assay was $16 \mathrm{pmol} / \mathrm{l}$ and the inter-assay $\mathrm{CV}$ at 300 and $497 \mathrm{pmol} / \mathrm{l}$ were 8.6 and $8.9 \%$, respectively. The antiserum exhibits no cross reactivity with GLP-1 (7-36) amide, glucagon, vasoactive intestial polypeptide (VIP), somatostatin, secretin, motilin, and GIP fragments 1-11,19-25 as well as 19-30.

The GLP-1 assay used in our assay has been described in detail previously $[16,17]$; synthetic GLP-1 (7-36) amide was used for the preparation of the standards and iodinated tracer (purified immediately before use by affinity chromatography) and the antiserum was raised in rabbits against synthetic GLP-1 (7-36)amide; a double antibody phase separation stage using a coating of donkey anti-rabbit second antibody on cellulose beads was used. The detection limit of the assay was 10 $\mathrm{pmol} / \mathrm{l}$ and the inter-assay CV was 17.8 and $15.4 \%$ at 22.6 and $64.5 \mathrm{pmol} / \mathrm{l}$ respectively. The antiserum exhibits no cross reactivity with GLP-2, glucagon, VIP, secretin, motalin, and GIP. The GLP-1 assay is directed against the C-terminal amide.

All samples were measured at the same time to minimise different assay conditions between different runs. Both our 


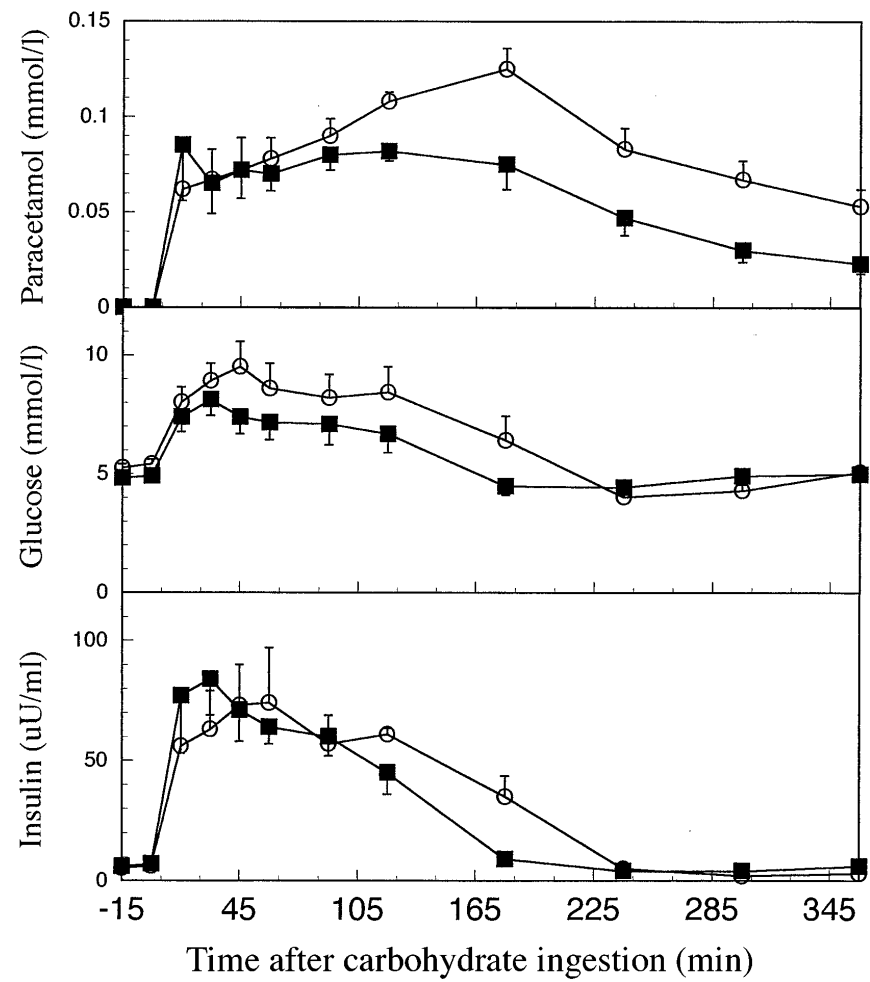

Fig.1. Paracetamol, glucose and insulin responses (Means \pm SEM) in young premenopausal and older postmenopausal women ( $n=6$ in each group), $-1-$ young, $\bigcirc$ old

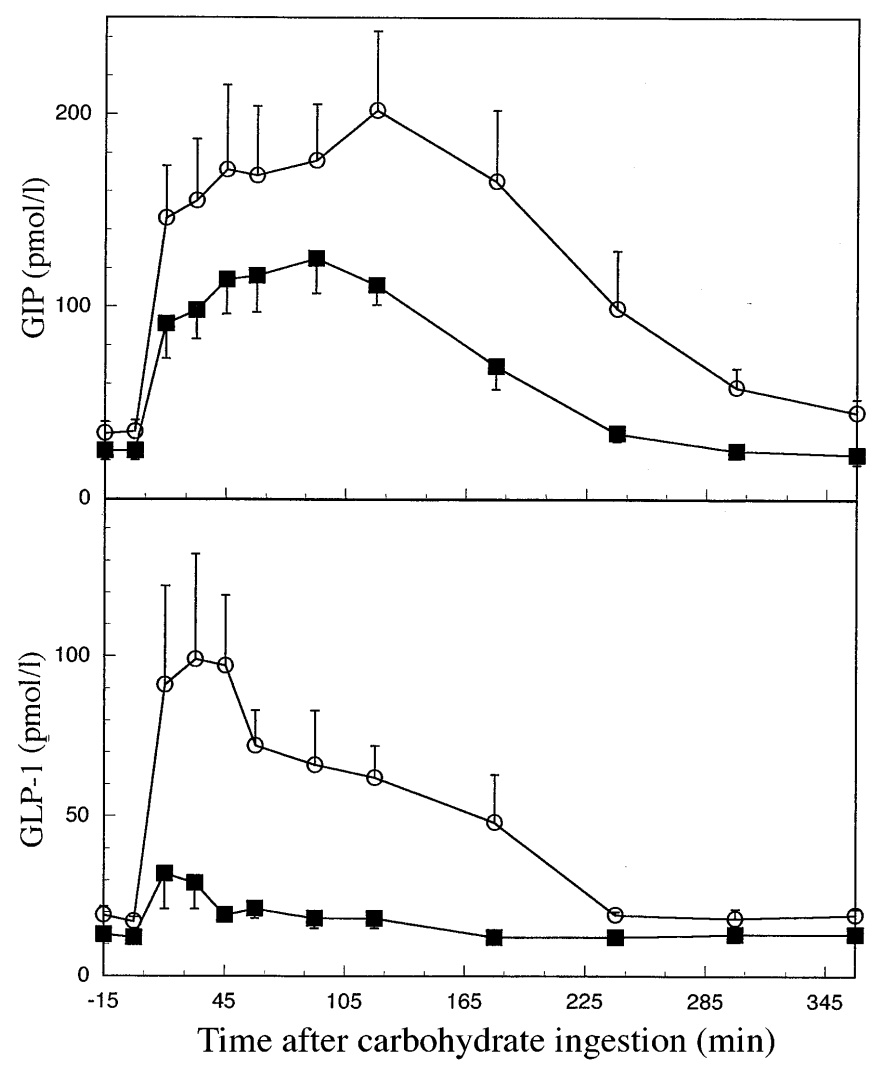

Fig. 2. GIP and GLP-1 responses (Means \pm SEM) in young premenopausal and older postmenopausal women $(n=6$ in each group), - - young, $\bigcirc$ old
Table 2. Total integrated responses (total under the curve; Means \pm SEM) for hormones and metabolites in younger and older subjects to $100 \mathrm{~g}$ oral carbohydrate

\begin{tabular}{lll}
\hline & $\begin{array}{l}\text { Younger group } \\
\text { Means } \pm \text { SEM }\end{array}$ & $\begin{array}{l}\text { Older group } \\
\text { Means } \pm \text { SEM }\end{array}$ \\
\hline Serum Paracetamol $(\mathrm{mmol} \cdot \min )$ & $20.8^{\mathrm{a}}(2.7)$ & $30.4(2.4)$ \\
Plasma Glucose $(\mathrm{mmol} / \mathrm{min})$ & $2065(78)$ & $2293(101)$ \\
Plasma Insulin $\left(\mu \mathrm{U} \cdot \mathrm{ml} \cdot \mathrm{min}^{-1}\right)$ & $9966(1080)$ & $11676(1774)$ \\
Plasma GIP $(\mathrm{pmol} / \mathrm{min})$ & $24452^{\mathrm{a}}(2606)$ & $46160(9403)$ \\
Plasma GLP-1 $(\mathrm{pmol} / \mathrm{min})$ & $5719^{\mathrm{a}}(652)$ & $16506(1823)$ \\
\hline
\end{tabular}

$n=6$ in each group; younger group significantly different from older; ${ }^{\mathrm{a}} p<0.05 ;{ }^{\mathrm{b}} p<0.001$

GIP and GLP-1 assays are homogenous assays not requiring extraction steps thereby minimising artefactual reduction of GLP-1 by processing.

Statistical analysis. Statistical analysis of the results was done using the Instat Graphpad Software (Guildford, UK) statistical package. Total and incremental integrated responses were calculated using the trapezoidal rule. Both integrated responses and individual time points for the groups were compared using unpaired Student's $t$-test. Pearson's correlation coefficient was used to assess the relation between sets of data. Values of $p$ less than 0.05 were considered significant.

\section{Results}

Fasting glucose and GLP-1 concentrations were higher in the older group (Table $1, p<0.04$ and 0.03 , respectively) but mean fasting insulin and GIP concentrations were similar in the two groups.

Glucose and insulin concentrations rose promptly to peak at between 30 and $60 \mathrm{~min}$ in both groups (Fig.1). They returned to near baseline values by $180 \mathrm{~min}$ in younger subjects and by $240 \mathrm{~min}$ in the older group. The integrated glucose responses showed a tendency towards higher values in the older compared with the younger group $(p<0.07)$ (Table 2). Insulin responses were similar in both groups.

Paracetamol integrated responses were higher in the older group $(p<0.02)$ although there was no difference for the first $90 \mathrm{~min}$ (Fig. 1).

After carbohydrate ingestion, both GIP and GLP-1 total integrated responses were considerably higher in the older group, approximately twofold for GIP and threefold for GLP-1 (Fig. 2). The GLP-1 and GIP responses were prompt in both groups, circulating concentrations reaching a peak at 30 and $120 \mathrm{~min}$, respectively. In the younger group, GLP-1 and GIP returned to baseline by 180 and $240 \mathrm{~min}$, respectively, but older subjects showed higher and sustained GLP-1 and GIP concentrations until 240 and $360 \mathrm{~min}$, respectively (the second being the end of the study period).

Age showed a positive correlation with total integrated responses of glucose $(r=0.65, p<0.02)$ and GLP-1 $(r=0.85, p<0.001)$. 


\section{Discussion}

In our study older subjects showed only higher fasting plasma glucose concentrations but no significant difference in integrated post-carbohydrate responses; this coupled with fasting and post-carbohydrate plasma insulin concentrations being also similar in both groups indicates that the older group showed only a minimum evidence of the insulin resistance that has often been described in elderly people $[1,2]$. This could, in part at least, reflect the fact that BMI was similar in both groups thus eliminating the confounding effect of obesity.

The plasma concentrations achieved following oral paracetamol treatment depends on the rate of gastric emptying, rate of absorption and clearance of paracetamol from the circulation. Paracetamol is rapidly absorbed from the small intestine $[14,15]$ and previous studies have shown no change in paracetamol absorption with ageing [15]; paracetamol responses in our study were similar for the first $90 \mathrm{~min}$ after oral ingestion and do not provide any support for rapid gastric emptying (plasma glucose and insulin responses at this time were also not increased; exaggerated glucose, insulin and paracetamol responses would be expected with a rapid entry of nutrients and paracetamol) $[18,19]$. There was a higher paracetamol integrated response overall and mainly after $90 \mathrm{~min}$ in the older group; however, significant impairment in paracetamol metabolism post-absorption has been shown in the elderly [20,21] and could have accounted for this difference.

The striking findings in our study are the considerably higher GIP and GLP-1 responses following carbohydrate ingestion in the older subjects. There are a number of possible explanations for these findings. More rapid gastric emptying and consequent rapid entry of nutrients into upper jejunum would be expected to result in patterns of both GIP and GLP-1 secretion similar to those observed but there was no supporting evidence for this in terms of glucose, insulin and paracetamol responses $[18,19]$. Primary idiopathy overproduction of GIP and GLP-1 from their cells of origin is possible but seems unlikely. In the circulation, GIP and GLP-1, are rapidly inactivated by dipeptidyl peptidases and carboxy-peptidases [22, 23]. Impairment of these and other (including renal) processes involved in clearance of these hormones from the circulation in the elderly could, in theory, lead to high concentrations of GIP and GLP-1; inappropriate accumulation of these hormones by this mechanism should lead, however, to lower glucose and higher insulin responses which we did not observe. The only forms of GLP-1 and GIP that are biologically active are GLP-1 (7-36 amide) and GIP (1-42) [12, 22]; enzymatic degradation in the circulation by peptidases converts these active hormones to inactive peptides GLP-1 (9-36 amide) or GIP (3-42)
$[12,22]$. Current immunoassays cannot reliably differentiate GLP-1 (7-36 amide) from GLP-1 (9-36 amide) or GIP (1-42) from GIP (3-24) [12, 24] which could partly explain the findings in this study.

Previous studies have showed that insulin secretion is impaired with ageing $[3,4,5]$ and that this could be due to failure of stimulus-secretion coupling $[7,9]$. This pathway of cyclic AMP-mediated insulin secretion has been shown to be impaired with ageing [9]. Since stimulation of the GLP-1 receptor results in the activation of the cyclic AMP pathway $[12,25]$, impairment of this second messenger system could lead to resistance to GLP-1 at the level of the betacell resulting in exaggerated release of GLP-1. Little is known about the regulation of receptors for GIP on islet cells but a similar mechanism cannot be excluded: the beta-cell has certainly been shown to be resistant to GIP in Type II diabetes [26].

Our study compared younger premenopausal with older postmenopausal subjects. It is possible that the differences between the two groups reflect differences in oestrogen status; evidence from studies on glucose and insulin metabolism in postmenopausal women however, do not lend support to this view. Insulin and glucose concentrations, both in the fasting state and in response to intravenous glucose have been found to be similar in premenopausal and postmenopausal women [27]. Previous studies on the effect of oestrogen therapy in postmenopausal women on glucose and insulin responses following oral glucose treatment either found no change [28] or a deterioration of glucose tolerance [29]. Hyperinsulinaemic euglycaemic clamp studies in postmenopausal women before and after oestrogen replacement therapy have also shown no difference [28].

The age of subjects fell into two groups and did not encompass the full range from 18 to 85 years; despite this, differences between the two groups are more likely to be due to age than the menopausal status. The strong correlation between age and GLP-1 seen in our study lends some support to this view but further studies are required to differentiate these two possibilities. The physiological importance of the augmented GIP and GLP-1 responses to carbohydrate described here remains to be clarified. If, as seems likely, it is a reflection of impaired beta-cell response to secretogogues, this study supports the existence of a negative feedback between incretin and insulin secretion, providing further evidence for the importance of the entero-insular axis in the regulation of insulin secretion. 


\section{References}

1. Harris MI, Hidden WC, Knowler WC (1987) Prevalance of diabetes and impaired glucose tolerance and plasma glucose levels in the U.S. population aged $20-74$ years. Diabetes 36: 523-534

2. Fitzgerald MG, Kilvert A (1985) Glucose tolerance and aging. In: Brockehurst JC (ed) Textbook of Geriatric Medicine and Gerontology. Churchill Livingstone, pp 718-719

3. Muller DC, Elahi D, Tobin JD, Andres R (1996) The effect of age on insulin resistance and secretion: a review. Semin Nephrol 16: 289-298

4. Scheen AJ, Sturis J, Polonsky KS, Van Cauter E (1996) Alterations in the ultradian oscillations of insulin secretion and plasma glucose in aging. Diabetologia 39: 564-572

5. Bourey RE, Kohrt WM, Kirwan JP, Staten MA, King DS, Holloszy JO (1993) Relationship between glucose tolerance and glucose-stimulated insulin response in 65-yearolds. J Gerontology 48:M122-M127

6. Shimizu M, Kawazu S, Tomono S et al. (1996) Age-related alteration of pancreatic beta-cell function. Increased proinsulin and proinsulin-to-insulin ratio in the elderly, but not in obese, subjects without glucose intolerance. Diabetes Care 19: 8-11

7. Borg LA, Dahl N, Swenne I (1995) Age-dependent differences in insulin secretion and intracellular handling of insulin in isolated pancreatic islets of the rat. Diabetes Metabol 21: 408-414

8. Perfetti R, Rafizadeh CM, Liotta AS, Egan Jm (1995) Agedependent reduction in insulin secretion and insulin mRNA in isolated islets from rats. Am J Physiol 269: E983-E990

9. Aizawa T, Komatsu M, Sato Y et al. (1994) Insulin secretion by the pancreatic beta cell of aged rats. Pancreas 9: 454-459

10. McIntyre N, Holdsworth CD, Turner DS (1964) New interpretation of oral glucose tolerance. Lancet II: 20-21

11. Morgan LM (1992) Insulin secretion and the entero-insular axis. In: Flatt PR (ed) Nutrient regulation of insulin secretion. The Biochemical Society, Portland Press, London, pp $1-22$

12. Fehmann HC, Goke R, Goke B (1995) Cell and molecular biology of the incretin hormones glucagon-like peptide-1 and glucose-dependent insulinotropic polypeptide. Endocr Rev 16: 390-410

13. Ranganath LR (1996) The role of glucagon-like peptide-1 and lipoprotein lipase in health and obesity. [Thesis] University of Surrey, Guildford, UK

14. Heading RC, Nimmo J, Prescott LF, Tothill P (1973) The dependence of paracetamol absorption on the rate of gastric emptyying. Br J Pharmacol 47: 415-421

15. Gainsborough N, Maskrey VL, Nelson ML et al. (1993) The association of age with gastric emptying. Age and Ageing 22: $37-40$
16. Elliott RM, Morgan LM, Tredger JA, Deacon S, Wright J, Marks V (1993) Glucagon-like peptide-1 (7-36)amide and glucose-dependent insulinotropic polypeptide secretion in response to nutrient ingestion in man: acute post-prandial and 24-h secretion patterns. J Endocrinol 138: 159-166

17. Morgan LM, Morris BA, Marks V (1978) Radioimmunoassay of gastric inhibitory polypeptide. Ann Clin Biochem 15: 172-177

18. Miholic J, Orskov C, Holst JJ, Kotzerke J, Meyer HJ (1991) Emptying of gastric substitute, glucagon-like peptide-1 (GLP-1), and reactive hypoglycaemia after total gastrectomy. Dig Dis Sci 36: 1361-1370

19. Miholic J, Orskov C, Holst JJ, Schaper S (1993) Postprandial GLP-1 in patients after esophageal resection, total gastrectomy and massive small-bowel resection. Digestion 54: 386-388

20. Triggs EJ, Nation RL, Long A, Ashley JJ (1975) Pharmacokinetics in the elderly. Eur J Clin Pharmacol 8: 55-62

21. Galinsky RE, Corcoran GB (1986) Influence of advanced age on the formation and elimination of acetaminophen metabolites by male rats. Pharmacology 32: 313-320

22. Mentlein R, Gallwitz B, Schmidt WE (1993) Dipeptidyl peptidase IV hydrolyses gastric inhibitory polypeptide, glucagon-like peptide-1 (7-36 amide), peptide histidine methionine and is responsible for their degradation in human serum. Eur J Biochem 214: 829-835

23. Maes M, Scharpe S, De Meester I et al. (1994) Components of biological variation in prolyl endopeptidase and dipeptidyl peptidase IV activity in plasma of healthy subjects. Clin Chem 40: 1686-1691

24. Schmidt WE, Siegel EG, Kummel H, Gallwitz B, Creutzfeldt W (1987) Commercially available preparations of porcine glucose-dependent insulinotropic polypeptide (GIP) contain a biologically inactive GIP-fragment and cholecystokinin-33/-39. Endocrinology 120: 835-837

25. Thorens B (1993) Recent studies on the GLP-1 receptors. Digestion 54: 341-342

26. Nauck MA, Heimesaat MM, Orskov C, Holst JJ, Ebert R, Creutzfeldt W (1993) Preserved incretin activity of glucagon-like peptide-1 (GLP-1) (7-36)amide but not of synthetic human gastric inhibitory polypeptide (GIP) in patients with type-2 diabetes mellitus. J Clin Invest 30: 301-307

27. Walton C, Godsland IF, Proudler AJ, Wynn V, Stevenson JC (1993) The effects of the menopause on insulin sensitivity, secretion and elimination in non-obese, healthy women. Eur J Clin Invest 23: 466-473

28. O'Sullivan AJ, Ho KK (1995) A comparison of the benefits of oral and transdermal oestrogen replacement on insulin sensitivity in postmenopausal women. J Clin Endocrinol Metab 80: 1783-1788

29. Godsland IF, Gangar K, Walton C et al. (1993) Insulin resistance, secretion, and elimination in postmenopausal women receiving oral or transdermal hormone replacement therapy. Metabolism 42: 846-853 